\title{
ARE CORPORATE UNIVERSITIES (CU) POSSIBLE IN EMERGING COUNTRIES? ARCOR UNIVERSITY (AU)
}

\author{
Dr. Leandro A. Viltard \\ Buenos Aires University, UBA, Argentina \\ E-mail: Iviltard@yahoo.com.ar
}

Submission: 22/12/2013

Revision: 06/01/2014

Accept: 10/01/2014

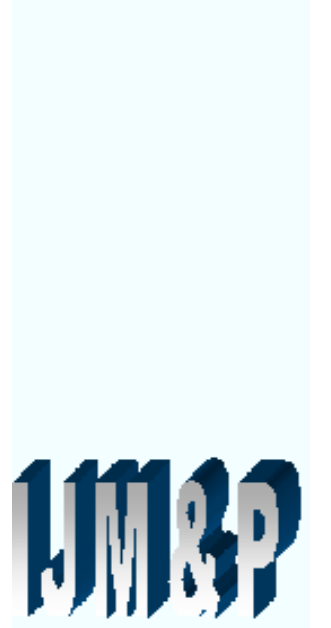

ABSTRACT

This article explores CU implementation and whether it is applicable and effective in emerging countries like Argentina (where there are no studies on the subject).

Through an in-depth review of Arcor University (AU), Arcor's Group CU, located in Argentina, the feasibility of the CU is shown, under certain conditions. This analysis is complemented with specialists' interviews to deepen our insights and investigation's results.

Our conclusion is that the CU complements Corporate Training's traditional offering, as its programs are directed towards practical contents and performance/organizational improvement. In this way, it is possible to enhance the actual corporate educational paradigm and talent employability.

The research design is not experimental and is transversal as it relates to a specific moment in time.

Keywords: Corporate University, Corporate education and training, Grupo Arcor, Arcor University, Emerging countries, Developing countries, Argentina, CU Implementation. 
INDEPENDENT JOURNAL OF MANAGEMENT \& PRODUCTION (IJM\&P)

http://www.ijmp.jor.br

v. 5, n. 3, June - September 2014

ISSN: 2236-269X

DOI: 10.14807/ijmp.v5i3.180

\section{INTRODUCTION}

Corporate Training (CT) is a boundless reign. Business Schools of Traditional Universities (TU), Traditional Corporate Training Departments (TCTD), independent professors and specialists (PS) and CUs are offering programs to a vast community of very busy professionals and companies' employees. In this environment, the questions that everybody asks are: How can we provide programs of excellence? How can we attract more students?

From one side, TU's Business Schools offer general programs to a wide variety of students; from the other, through TCTD and PS there are directed offers to improve specific needs and performance in the corporate world. But, what the CU has introduced is the possibility of developing strategic and operational matters in a holistic and collaborative way. From this point of view, the $\mathrm{CU}$ has newly emerged as the source of people's contribution and participation, aligning strategic and operational objectives within organizations (ALLEN, 2007).

It is needless to say that both worlds are necessary; the "traditional", basically referring to theoretical matters, and the "new", referring to practical and day to day issues. Consequently, the educational roles and limits are under constant pressure and analysis (MEISTER, 2000).

The main hypothesis of this investigation considers that the $\mathrm{CU}$ complements what is taught at TUs and, well applied, enhances what TCTDs are doing. Its implementation contributes to a more practical content directed to performance and organizational improvement. ${ }^{1}$

\subsection{Design: Methodology \& Analysis}

This analysis is based on a study of AU study (from Grupo Arcor, Argentina) and five interviews with key specialists to better understand the $\mathrm{CU}$ phenomenon.

The study is exploratory and descriptive. It uses a qualitative methodology and a non-experimental design (it is transversal, as the information was collected at a given moment of time).

${ }^{1}$ If there were needs to better understanding the CU importance, refer to article cited in 1. .

[http://creativecommons.org/licenses/by/3.0/us/]

Licensed under a Creative Commons Attribution 3.0 United States License 
INDEPENDENT JOURNAL OF MANAGEMENT \& PRODUCTION (IJM\&P)

http://www.ijmp.jor.br

v. 5, n. 3, June - September 2014

ISSN: 2236-269X

DOI: 10.14807/ijmp.v5i3.180

$\mathrm{AU}$ and $\mathrm{CU}$ s in general were the units of analysis. AU was selected directly and intentionally.

The response units were the AU Head (B.S. María Belen Vallone, meeting held on 05/14/2009) and the specialists interviewed.

This research was done in Argentina between Jan. 2009 and May 2012.

\subsection{Research Limitations/Clarifications}

- Although we recognize that it is very difficult to ascertain that all relevant information has been included, we referred to worldwide information from relevant secondary sources.

- $A U$ was selected intentionally as there were not many other CUs implemented in Argentina. In order to get a better understanding of this phenomenon, we tried to contact other CU's executives but, for instance, Techint Group -which had Tenaris University - were unable to respond as they had disputes with the Venezuelan and Argentinean governments.

- The information given by the AU Head was the most we could obtain as there were some areas in which they couldn't disclose information.

- The interviews with key specialists and the AU Head were held in their offices in order to have a minimal impact on their environment and, finally, on the interview results. We used semi-structured interviews in order to enrich, as much as possible, this investigation's results.

- $\quad$ The AU case and the specialists' interviews were utilized as a way to collect information from the field. As a result, we haven't used a triangulation with other data collection techniques to better guarantee the results of this investigation.2

\footnotetext{
${ }^{2}$ For further assurance on conclusions and results, please refer to: Viltard, L. A. (2014) "Are Corporate Universities (CU) possible in emerging countries?, A survey conducted in Argentina showed impacting results, International Journal of Management \& Production, Sao Pablo, Brazil. In this article and through a self-designed survey, it is analyzed the CU status in Argentina as an emerging country. As a conclusion, triangulation is possible among both articles.
} 
INDEPENDENT JOURNAL OF MANAGEMENT \& PRODUCTION (IJM\&P)

http://www.ijmp.jor.br

v. 5, n. 3, June - September 2014

ISSN: 2236-269X

DOI: 10.14807/ijmp.v5i3.180

- Not to undermine the content and the investigation's purpose, the conclusions and opinions that were expressed are strictly based on the information obtained from the analyzed data.

As a qualitative investigation, the results that are shown cannot be generalized, although they are useful for decision making purposes. Our aim is to enhance CU knowledge and conclude on its implementation possibilities in Argentina as emerging country (KRASKA, 2006).

\subsection{Findings}

Under certain conditions, international market expansion, company size and right executive's mentality, the CU concept is feasible in an emerging country like Argentina. The $\mathrm{CU}$ is reinforced as a way to enhance the actual educational paradigm and talent employability, through proposing a homogeneous and powerful knowledge management environment.

\subsection{Originality and Value}

CUs are not common in Argentina and studies on this matter have not been made.

We are sure that the study of this phenomenon could help in Corporate Training (CT) progress and individual education improvement. Additionally, input from the local and foreign specialists' give a solid theoretical base to support the findings of this investigation.

\subsection{Objective of this investigation}

To better understand the CU implementation context in Argentina and determine if it could enhance the actual corporate educational paradigm and talent employability (continuing education).

\section{GRUPO ARCOR - ARGENTINA}


INDEPENDENT JOURNAL OF MANAGEMENT \& PRODUCTION (IJM\&P)

http://www.ijmp.jor.br

v. 5, n. 3, June - September 2014

ISSN: 2236-269X

DOI: 10.14807/ijmp.v5i3.180

The entrepreneur tradition in Argentina presents an uneven picture and, generally, a lack of competitive strength and global recognition. We can find some explanations in the following facts:

- Closeness that has existed between governments and groups of power, impacting their independence,

- Lack of stable policies to encourage international firm's development, and

- The continuous political and economic fluctuations which have not created the necessary conditions for business, such as exchange rate and tariff policies.

Within this environment, it was difficult to find enterprises that exceeded the local level with a successful track record and long term views. In this sense, the most common reason used as a justification for not implementing actions that went beyond the daily activities were related with SME's size (forgetting that every firm begins small) and financial difficulties. It was understood that the comfort zone of many executives and firms was a real danger and those arguments should be reviewed.

Grupo Arcor SAIC (from now on, Arcor) is one of the two largest food firms in Argentina, exporting, mainly candies, to 120 countries (2008 exports totaled $\$ 310$ million). Some impacting figures of this holding showed: 2009 annual revenue of $\$ 2,300$ million and nearly 20,000 total employees (of which 14,000 in Argentina); 41 manufacturing plants; 13 distribution centers located in LA; 12 sales offices in America, EU, Asia and Africa; +1500 products manufactured and +100 launched a year. Also, they have vertically integrated strategic inputs, with two packaging companies (Cartocor SA and Converflex SA). Through Bagley LA SA is the largest South American cookies' firm.

Ethics and tradition are very important for this holding, and Luis Pagani, Group's Chairman, has remained as one of the most prestigious entrepreneurs in Argentina. Surely, many companies in the world would like to imitate Arcor's results. 
INDEPENDENT JOURNAL OF MANAGEMENT \& PRODUCTION (IJM\&P)

http://www.ijmp.jor.br

v. 5, n. 3, June - September 2014

ISSN: 2236-269X

DOI: 10.14807/ijmp.v5i3.180

\section{ARCOR UNIVERSITY (AU) ${ }^{3}$}

We chose $A U$ because it sparked our interest as researchers due to its particular character and significance, as well as the high interest that it might have for the academic and business community. It had been little studied due to its recent implementation and, also, because of issues of confidentiality. Through AU analysis there would be better insights on $\mathrm{CU}$ possibilities in an emerging country like Argentina (DEALTRY, 2005; DEALTRY, 2000).

AU was founded in 2007-2008. Previously, CT within Arcor has been headed in each Business Unit (BU) through individuals TCTDs, causing value chain inefficiencies, especially in human resources training (e.g.: incomplete educational offer, partial approaches and non-homogeneous content and courses).

Thanks to $A U$, significant changes have been noted in their business environment, impacting processes and stakeholders. Individual skills and relevant shared knowledge have been built, using it also as a support for new strategy definition. Additionally, $\mathrm{AU}$ has been considered as the engine to promote organizational and technological change, helping in talent attraction and retention (KERKER, 1999).

Key aspects of its implementation are summarized below:

- 2006 - Redefinition of the vision, mission and strategic objectives of the Group, and as a consequence, a new competency map for every function and individual was put in place.

- 2007 - AU emerged lead by the Group President and the HR General Manager. The following steps were followed:

o A definition and scope of organizational learning,

o $\mathrm{BU}$ and $\mathrm{AU}$ responsibilities' allocation,

o CT key processes set up, and finally

\footnotetext{
${ }^{3}$ All the information and details throughout this section have emerged from the interview with M. B. Vallone - UA Manager - Arcor Group.
} 
INDEPENDENT JOURNAL OF MANAGEMENT \& PRODUCTION (IJM\&P)

http://www.ijmp.jor.br

v. 5, n. 3, June - September 2014

ISSN: 2236-269X

DOI: 10.14807/ijmp.v5i3.180

o CU implementation issues and the leaders' role definition.

- Critical points were considered to enhance the expected results: Organizational alignment with business strategy; people performance improvement throughout the value chain; and learning acquisition time enhancement to optimize costs.

- As with every new process, AU was aligned to the existed HR processes, improving actual competencies and developing new ones.

- Through the educational and training reengineering the following soft skills were developed: leadership, business, change, management and initiative. Industry skills were also developed, as well as others to improve employees' careers within the organization (e.g.: special programs for young professionals, middle and management development).

- Three implementation scenarios were raised. The first one (operative stage) was more connected with organization of courses, efficiency and, to a lesser extent, with the global strategy. The last one (strategic scenario) identified that $\mathrm{AU}$ was the company's knowledge backbone through generation, transfer and retention of skills necessary to build competitive advantage.

- A long implementation lead time of 3 years was established but the higher priority was assigned to the fact that the entire organization should accept $\mathrm{AU}$ principles and practices, not being fixed to tied implementation schedules. There were 3 phases defined, each of which would be accomplished in one year, as follows:

o Development phase: This step was crucial to introduce AU to the organization and obtain each executive's support to the project. The main tasks of this phase were to:

- Validate the proposed model

- Align contents with the competency model

[http://creativecommons.org/licenses/by/3.0/us/] 
- Develop a methodology to assess and certify consultants, trainers and programs

- Select skills' specialists to better control education

- Develop specific curricula

- Contact the right suppliers/teachers

- Design corporate programs and web site

o Implementation phase: Students' enrollment was the start up point. The AU training should agree with the new and broader scope that was defined. The most significant tasks of this phase were to:

- Publish the corporate educational offer

- Assemble an annual training calendar

- Deliver corporate programs

- Publish the training process guidelines (budget, student's enrollment, etc.)

- Launch AU progressively and validate its programs

- Implement a training evaluation system

o Consolidation stage: This stage involved a huge risk as all the effort invested in the prior two stages could vanish. Thus, Arcor defined the following tasks for this sensitive stage:

- Managing the continuity of corporate programs

- Renewing and extending each offer periodically

- Certifying and re-certifying suppliers/providers

- Auditing the designed programs; and knowledge base management 
INDEPENDENT JOURNAL OF MANAGEMENT \& PRODUCTION (IJM\&P)

http://www.ijmp.jor.br

v. 5, n. 3, June - September 2014

ISSN: 2236-269X

DOI: 10.14807/ijmp.v5i3.180

The next stage was the Schools of Specialization; they would expand and deepen the knowledge of certain topics within Arcor. At the moment of our review, there were not many details on this subject (CHIVERS, 2000).

- IT tools were needed to carry out AU implementation. A platform was built which included features such as a newsletter, surveys, digital library, photo gallery, etc. All this enhanced the individual learning process, generating ongoing communication on training programs. This platform was autonomously managed by HR, not depending on programmers for updates and modifications.

- Convinced about its benefits, Arcor provided the funds for AU. As a result, profits were not their objective, but instead efficiency and service to the organization.

- Courses were in association with TUs or specialists, and were delivered online (e-learning) or in classrooms. After manager's approval, each employee could sign up for a course.

- The following results show how successful AU was:

o When the AU began in 2008, 9 hours per capita was the average man/hours of training. In the period 2008-2011 this figure dramatically increased by $144 \%$.

o The proportion of classroom courses versus e-learning remained constant when comparing years 2008 and 2009. In 2008, a total of 38,638 hours were invested in the various programs, of which 33,098 (86\%) correspond to classroom courses and $5,540(14 \%)$ to elearning. In Jan-August 2009 the total hours invested were 13,381, of which $11,198(84 \%)$ correspond to classrooms courses and 2,183 $(16 \%)$ to e-learning.

These results are better shown in the following tables: 
INDEPENDENT JOURNAL OF MANAGEMENT \& PRODUCTION (IJM\&P)

http://www.ijmp.jor.br

v. 5, n. 3, June - September 2014

ISSN: 2236-269X

DOI: 10.14807/ijmp.v5i3.180

Table 1: $\mathrm{AU}$ results ${ }^{4}$

\begin{tabular}{|c|c|}
\hline Year & $\begin{array}{c}\text { Man/hours of } \\
\text { training }\end{array}$ \\
\hline Up to 2008 & 9 hours \\
\hline $2008-2011$ & 21.96 hours \\
\hline Increase $\%$ & $144 \%$ \\
\hline
\end{tabular}

\begin{tabular}{|l|c|c|c|c|c|c|}
\hline \multicolumn{1}{|c|}{ Period } & $\begin{array}{c}\text { Total } \\
\text { hours } \\
\text { invested }\end{array}$ & $\%$ & $\begin{array}{c}\text { Classroom } \\
\text { courses } \\
\text { (hours) }\end{array}$ & $\%$ & $\begin{array}{c}\text { E-learning } \\
\text { courses } \\
\text { (hours) }\end{array}$ & $\%$ \\
\hline 2008 & 38,638 & 100 & 33,098 & 86 & 5,540 & 14 \\
\hline Jan-Aug. 2009 & 13,381 & 100 & 11,198 & 84 & 2,183 & 16 \\
\hline
\end{tabular}

AU's implementation is possible to be seen as a process, with its inputs/outputs, and implementation scenarios and lead times schedule, as per the following diagram:

\section{Diagram 1: AU implementation details}

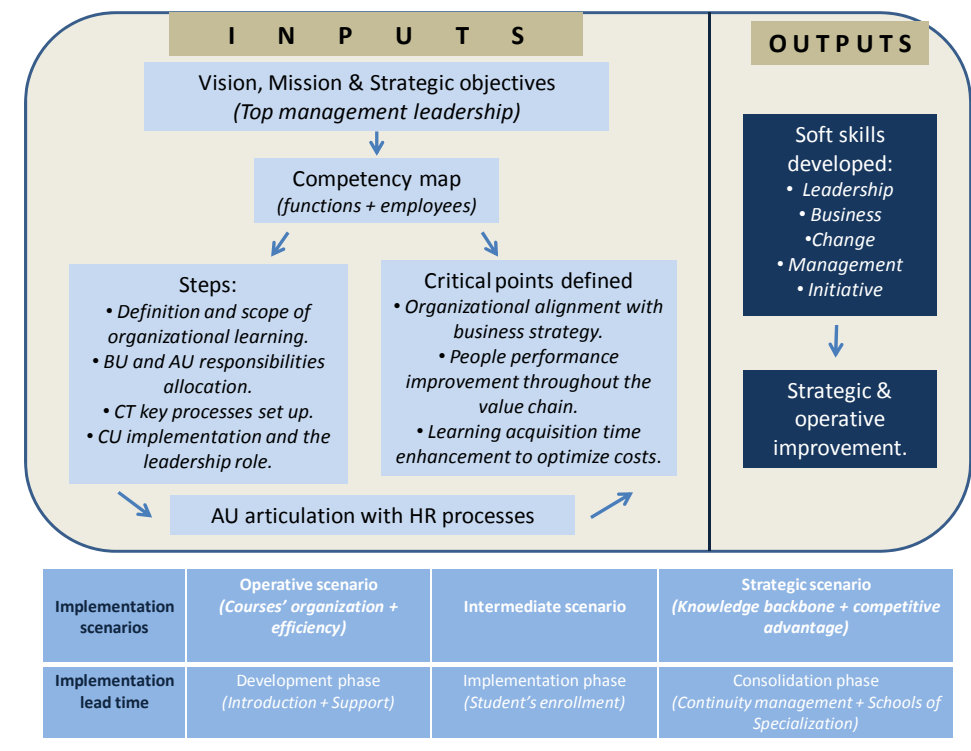

${ }^{4}$ Comparisons were made with the available data given by UA Manager - Arcor Group. That is why in "man/hours of training" we are comparing the period 2008-2011 and in "invested hours" the period is 2008Aug. 2009. 
INDEPENDENT JOURNAL OF MANAGEMENT \& PRODUCTION (IJM\&P)

http://www.ijmp.jor.br

v. 5, n. 3, June - September 2014

ISSN: 2236-269X

DOI: 10.14807/ijmp.v5i3.180

\section{SPECIALISTS INTERVIEWED}

Specialists were interviewed to expand and deepen our analysis, allowing us to gain more insights on the corporate and traditional educational environments.

E. Gore (a recognized corporate training specialist and University Professor) suggested that the $\mathrm{CU}$ has not been more developed as Argentinean industry was not highly developed and, also, for political and economic reasons. Additionally, he pointed out that, in these kinds of environments, what a company does is not limited by conviction, but by restriction. As a consequence, their goals are a result of these restrictions, hampering future development and growth (DEALTRY, 2001).

While comparing the TU with the CU, some experts pointed out budget and investment differences. They understood that TUs in LA have been through difficult processes over time, linked to strong political-social-cultural-economic (PSCE) fluctuations, which have had great influence on inward $\mathrm{FDI}^{5}$ and its development potential. Those fluctuations/restrictions are in line with what Gore remarked on Argentina as a developing country (VILTARD, 2014).

A group of specialists considered that the CU complements what is taught at TUs and enhances what TCTDs are doing. Also, they said that CUs are focused on more practical content directed to performance and organizational improvement while the TU focus was on more theoretical matters. As a result, it was understood that there were areas of improvement for TUs and CUs, and role redefinition was a must (MEISTER, 2000).

An interesting point of view remarked that both the TU and CU were struggling against standardization and differentiation. The TU tends to standardize skills in a greater number of people, so that their education has a much lower intensity when compared with the CU. In turn, the CU seeks differentiation in specific skills for a small number of individuals, so that its intensity is much higher (KERKER, 1999).

\footnotetext{
${ }^{5}$ Foreign Direct Investment (FDI) is a direct investment into production or business in a country by an
} individual or company of another country.

[http://creativecommons.org/licenses/by/3.0/us/]

Licensed under a Creative Commons Attribution 3.0 United States License 
INDEPENDENT JOURNAL OF MANAGEMENT \& PRODUCTION (IJM\&P)

http://www.ijmp.jor.br

v. 5, n. 3, June - September 2014

ISSN: 2236-269X

DOI: 10.14807/ijmp.v5i3.180

The CU was seen as giving high potentialities when handled as a dependent $B U$ of major corporations. This dependency implied the $C U$ as a liaison with $H Q$ on policies and strategy but, also, CU self-financing and its non-discretionary resources management (DEALTRY, 2000; CHIVERS, 2000).

Interviewed specialists also suggested that a CU's benefits were to develop and transfer global business visions throughout the entire organization through the strict connection of classrooms activities with everyday tasks. It was reinforced by the location of the $\mathrm{CU}$ near the $\mathrm{HQ}$, guaranteeing understanding, acceptance, dissemination and stronger commitment to policies and strategies within the whole organization ${ }^{6}$.

Specialists interviewed agreed that continuing education becomes essential for talent employability and organizational growth. But there were different opinions on continuing education; some preferred isolated or sporadic educational proposals, while others thought that centralized and holistic approaches, aligned to strategic and long term views, were more comprehensive ${ }^{7}$. So, it was indicated that the CU could help to combat an individual's isolation caused by factors such as daily work pressures, and not participating and sharing plans at all levels.

In this sense, another investigation ${ }^{8}$ identified that the most frequent reasons given for $\mathrm{CU}$ implementation were linked to the need for a central space for learning; knowledge and culture dissemination; developing a company's sense of belonging; promotion of a discussion forum and common language for business; competitive advantage creation and maintenance and, finally, the education and training of internal and external people.

Also, specialists reinforced the idea that the $\mathrm{CU}$ could benefit strategic, business and operational development and continuing education through everybody's participation and collaboration.

\footnotetext{
${ }^{6}$ These matters were also remarked in our article cited in 1 .

${ }^{7}$ Idem 4.

8 Ídem 4 
INDEPENDENT JOURNAL OF MANAGEMENT \& PRODUCTION (IJM\&P)

http://www.ijmp.jor.br

v. 5, n. 3, June - September 2014

ISSN: 2236-269X

DOI: 10.14807/ijmp.v5i3.180

In our opinion, and facing exasperated knowledge obsolescence, the CU could be the liaison between top management and employee initiatives, and continuing education is a must for organizational and individual growth. Thereby, the CU could be seen as the environment where strategic and operative changes could happen.

As a consequence, specialists visualize that the leader's job was focused on obtaining value propositions through the participation of the greatest number of people. They concluded that talent depends on issues such as innovation, negotiation, communication and leadership, which represent assets that an updated professional must offer and that the CU can help to develop. At this point, we agree with Senge $(1990)^{9}$ when he indicated that learning organizations are not a fad, but a new perspective on practical knowledge. The CU could be seen as the place where learning organizations emerge.

As a summary, we propose the following table in which we remark $\mathrm{CU}$ positive and negative signs, and risks involved:

Table 2: CU positive and negative signs + risks involved ${ }^{10}$

\begin{tabular}{|c|c|c|}
\hline Positive signs & Negative signs & Risks \\
\hline $\begin{array}{l}\text { CU handled as a BU as a } \\
\text { central space of learning } \\
\text { acquisition and distribution. }\end{array}$ & $\begin{array}{l}\text { Emerging countries' industry } \\
\text { with strong PSCE fluctuations. }\end{array}$ & $\begin{array}{l}\text { Continuing education for } \\
\text { talent employability and } \\
\text { organizational growth. }\end{array}$ \\
\hline $\begin{array}{l}\text { CU develops and transfers } \\
\text { global business visions and } \\
\text { strategies. }\end{array}$ & $\begin{array}{l}\text { Firm's goals are set up limited } \\
\text { by restriction, not by conviction. }\end{array}$ & $\begin{array}{l}\text { The limits of standardization } \\
\text { and differentiation. }\end{array}$ \\
\hline $\begin{array}{l}\text { CU helps in participation and } \\
\text { collaboration. }\end{array}$ & $\begin{array}{l}\text { Budget and investment } \\
\text { difference between TU and CU. }\end{array}$ & $\begin{array}{l}\text { Isolation and knowledge } \\
\text { obsolescence. }\end{array}$ \\
\hline
\end{tabular}

\footnotetext{
${ }^{9}$ Peter Senge (1990). The fifth discipline. The art \& practice of the Learning Organization. Doubleday, New York.

${ }^{10}$ In this table there are shown elements that are connected to what it is proposed by Fresina (1999), cited in the article: Viltard, L. A. (2014) "Are Corporate Universities (CU) possible in emerging countries?, A survey conducted in Argentina showed impacting results, International Journal of Management \& Production, Sao Pablo, Brazil.
} 
INDEPENDENT JOURNAL OF MANAGEMENT \& PRODUCTION (IJM\&P)

http://www.ijmp.jor.br

v. 5, n. 3, June - September 2014

ISSN: 2236-269X

DOI: 10.14807/ijmp.v5i3.180

The purposes of corporate university include (1) as reinforcing and perpetuating current cultures and competitiveness; (2) as agents to manage and implement change; and (3) as a force to drive and shape the future strategy of the organization. (FRESINA, 1997) The authors may check if there are any differences/ similarities in $\mathrm{CU}$ positive and negative signs between $\mathrm{AU}$ and previous literature.

\section{CONCLUSIONS}

The CU was not a widespread concept in Argentina, where additional inconveniences were faced when compared to developed countries. Thus, complex and competitive situations were hampering growth and the competitive environment in developing countries like Argentina ${ }^{11}$. Few leaders had the opportunity to be focused on long term projects, as short term projects were the most considered in the vast majority of firms.

Knowledge and competencies were managed with sporadic and not centralized and integrated procedures. Within the Argentinean corporate tradition, Grupo Arcor was an atypical reality, as it had been a vigorous and responsible business player for long time. A clear direction and mentality has driven their results, showing that, under certain conditions, $A U$ was feasible in this context.

Arcor implemented $\mathrm{AU}$ when the firm reached a certain size and was seeking further expansion in the international markets. It was not possible to say that their particular industry favored AU implementation. Their clear strategic definition and alignment to functional competencies had been the start up of this project.

The objectives, as a focal point for $A U$, covered strategic change supported by learning; common culture widespread; knowledge transfer/retention; competitive advantage creation; and operational efficiencies, as the most relevant noted.

AU has proposed new alternatives for CT, enhancing individual skills and abilities, and market positioning.

${ }^{11}$ Are Corporate Universities (CU) possible in emerging countries? - A survey conducted in Argentina showed impacting results 
INDEPENDENT JOURNAL OF MANAGEMENT \& PRODUCTION (IJM\&P)

http://www.ijmp.jor.br

v. 5, n. 3, June - September 2014

ISSN: 2236-269X

DOI: 10.14807/ijmp.v5i3.180

Responsibilities were a focal point in $\mathrm{AU}$ implementation. That is why, $\mathrm{BU}$, $A U$ and leader's responsibilities were defined in order to embark every executive and every employee on the new direction.

The performance management system provided an individual source of information that $A U$ would turn into key elements for organizational success. As a consequence, $\mathrm{AU}$ was defined, not only as an educational institution, but also as a strategic business tool which would improve the individual and collective learning.

To improve results, AU's new processes were linked and articulated to those that already existed in HR (selection, performance, climate survey, compensation, transfers, etc.).

As change should be generated from each individual, it was necessary to start with an inventory of skills, training and performance for everyone. As a result, the training offer (based on soft skills such as leadership, business, change, and initiative) should meet the individuals' current and future needs, in accordance with company objectives.

AU implementation solved HR and many operational problems, and brought synergies to Arcor (for example: $A U$ and $B U$ roles separation, policies and monitoring on CT). Moreover, AU supported operational issues generating:

- Comprehensive visions of the problems and quality standards,

- Standardization of key processes, skills development and training policies,

- Reducing inefficiencies and redundant activities.

As a consequence, AU was approached as an organizational economy of efforts and, also, as a way to release new energies to be applied for creative and far more constructive matters.

It used a mixed educational method (classroom and online), as a way to reach as many internal students as was possible, offering them availability and flexibility. 
INDEPENDENT JOURNAL OF MANAGEMENT \& PRODUCTION (IJM\&P)

http://www.ijmp.jor.br

v. 5, n. 3, June - September 2014

ISSN: 2236-269X

DOI: 10.14807/ijmp.v5i3.180

Stage certifications and key performance indicators were vital for AU followup and improvement. The Schools of Specialties indicated that there was a need for a deeper knowledge and that the project would not stop.

Financially, AU was considered as a cost center, a service to other BUs, with an annual budget; it was not for profit, but instead was directed to knowledge and educational results. Although we believe that this approach represented a concrete support to $A U$, we could also argue that if top management would allow its self-sufficiency in a period of time; this would have meant a more growth-oriented external positioning. However, we emphasize that each company must define its CU funding without preconceptions, as this decision is related to complex and individual factors.

The AU success story has come from a strategic plan definition, which has recognized the entrepreneurial spirit and top management commitment. As a result, $\mathrm{AU}$ has provided tangible benefits to Arcor and surely, more firms should follow its path.

It was discovered that such a mentality and a dominant logic tied to old patterns influence the acceptance and implementation of long term new projects in emerging countries like Argentina. But as a result of our analysis, the CU appeared to be applicable and valid in this environment, under certain conditions. It was also identified that the CU complements what TUs and traditional educational programs (e.g. TCTD and PS), contribute to a more practical content directed to performance and organizational improvement.

Through this investigation there were elements that provided a better understanding of the $\mathrm{CU}$ implementation context in Argentina, enhancing the actual corporate educational paradigm and talent employability (continuing education).

As a result, the $\mathrm{CU}$ is not related to emerging or developed countries, or specific industries, but has limits and influences on CTs, TUs and TCTDs.

Finally, throughout this investigation the hypothesis was confirmed and the objectives verified. 


\section{REFERENCES}

ALLEN, M. (2007). The next generation of Corporate Universities. Santiago de Chile, Chile: Pfeiffer.

CHIVERS, G. (2000). Corporate Universities: First lessons from a European learning group, Journal of European Industrial Training, v. 35, n.2.

DEALTRY, R. (2005). Achieving integrated performance management with the corporate university. Journal of Workplace Learning, n. 17, p. 65-78.

DEALTRY, R. (2000). Case research into corporate university developments. Journal of Workplace Learning, v. 12, n. 6, ISBN: 9780952300748

DEALTRY, R. (2001). How to configure the corporate university for success? Journal of Workplace Learning, v. 13, n. 2, ISBN: 9781904481010

KERKER, S. (1999).A Corporate University Consortium is the missing link. Corporate University Review, v. 7, n. 6, p. 3.

KRASKA, B. (2006). 7 Ways to ensure your CU succeeds. Training, v. 43, n. 9, p. 16.

MEISTER, J. (2000). Corporate Universities: An Interview with Jeanne Meister by James L. Morrison and Jeanne C. Meister. North Caroline, USA: University of North Caroline. 